\title{
Restorative Justice in Settlement of Criminal Action of Grievant Delicion
}

\section{Nugraha $^{*}$ and Sukarmi ${ }^{* *}$}

*) Student of Master of Law, Faculty of Law, Universitas Islam Sultan Agung Semarang and Advocates, E-mail: nugraha.alqadhli@gmail.com

${ }^{* *}$ Faculty of Law, Universitas Islam Sultan Agung Semarang

\begin{abstract}
.
The objectives of this research are: To find out and analyze Restorative justice in the criminal law system in Indonesia. To find out and analyze the implementation of Restorative justice in the settlement of criminal complaints offenses. To find out and analyze the constraints on the implementation of Restorative justice in the settlement of criminal offenses complaints and their solutions. The method used by researchers isjuridical empirical legal approach and the specification in this research is including analytical descriptive. Based on the results of that research Restorative justice in the criminal law system in Indonesia, namely focusing on the needs of both victims and perpetrators of crimes. In addition, the Restorative justice approach helps criminals to avoid other crimes in the future. The implementation of Restorative justice in the settlement of criminal cases of complaint offenses at the Cirebon City Police using a retributive approach (retaliation) can shift to a restorative approach (recovery). The obstacle: The investigative authority granted by the Criminal Procedure Code. In the Criminal Procedure Code, investigators are given the authority to stop an investigation on the basis of the consideration that it is not a criminal act, insufficient evidence as a criminal act, and for the sake of the law. KUHAP regulates the withdrawal of reports or complaints only for certain cases, namely those which constitute offenses for complaints. The solution: In accordance with social jurispurdence theory. Propose to the highest leadership to formulate definite rules or organizational mission and the purpose of establishing a system (legalization) for the application of Restorative justice. Outreach to the community.

Keywords: Restorative justice; Crime; Complaint Offense.
\end{abstract}

\section{Introduction}

As a rule of law that upholds the value of civilization based on Pancasila and the 1945 Constitution of the Republic of Indonesia, the Indonesian nation always places respect for human dignity in all aspects of the nation, state and society. This is based on the understanding that human rights are basic rights inherent naturally in every human being, including persons with disabilities. These rights are universal, lasting, cannot be reduced, limited, obstructed, let alone revoked or eliminated by anyone including the State.

The issue of justice and human rights in relation to criminal law enforcement is not an easy job to realize. One example of the lack of attention to issues of justice and human rights in criminal law enforcement is related to legal protection for victims. Victims are those who suffer both physically and spiritually as a result of the actions of others who seek fulfillment for themselves or others that are 
contrary to the interests and rights of those who suffer. ${ }^{1}$ Victims of crime, who are basically the party who suffer the most in a crime, do not receive the protection as mandated by law. As a result, when the perpetrator of a crime has been sentenced to a criminal sanction by the court, the condition of the victim of the crime seems to be completely ignored. According to criminological and criminal law views, crime is a conflict between individuals that causes harm to the victim, the community and the offender himself, where of the three groups, the interests of "crime victims" are the main part of crime, as according to Andrew Ashworth: "primary an offence against the victim and only secondarily an offence against the wider comunity or state".

The criminal justice system is offender oriented, which puts forward the rights of the suspect or defendant as stated by Andi Hamzah: "In discussing criminal procedural law, especially those related to human rights, there is a tendency to discuss matters relating to the rights of the suspect without paying attention to the rights of the victims. The victim is not given authority and is not actively involved in the investigation and trial process so that he loses the opportunity to fight for his rights and restore his condition as a result of a crime".2

Offender oriented punishment results in the perpetrator as the main subject in a crime so that the sanctions given sometimes cause a sense of injustice for the perpetrator. Crime in general must involve two parties, namely the perpetrator and the victim, although in reality there are several crimes that occur without a victim, in the sense that the perpetrator of the crime is also the victim, such as: gambling and drug abuse. ${ }^{3}$

Based on the above problems, the objectives of this study are as follows: To identify and analyze Restorative justice in the criminal law system in Indonesia; To find out and analyze the implementation of Restorative justice in the settlement of criminal complaints offenses; and To find out and analyze the constraints of implementing Restorative justice in the settlement of criminal complaints offenses.

\section{Research methods}

The approach method used in this research is juridical empirical, which has the intention of examining both juridical and empirical aspects. The research specification used in this research is descriptive analytical, that is, from this research it is expected that a detailed and systematic description of the problem to be studied is obtained. The analysis is intended to be based on the description, the facts obtained will be analyzed carefully to answer the problem. ${ }^{4}$

\footnotetext{
1 Waluyo, Bambang. (2012). Viktimologi perlindungan korban dan saksi. Jakarta: Sinar Grafika. p. 2.

2 Dikdik M. Arief Mansur \& Elisatri Gultom. (2008). Urgensi Perlindungan Korban Kejahatan Antara Norma Dan Realita. Jakarta: Raja Grafindo. p. 25.

3 Widiartana, G. (2014). Viktimologi Perspektif Korban dalam Penanggulangan Kejahatan. Yogyakarta: Universitas Atma Jaya. p. 5

${ }^{4}$ Hartono, Sunaryati. (1994). Penelitian Hukum Indonesia Pada Akhir Abad ke-20. Bandung: Alumni. p. 101.
} 


\section{Result and Discussion}

\subsection{Restorative justice In the Criminal Law System in Indonesia}

In criminal law enforcement practice, we often hear the term Restorative justice, or Restoration Justice which in Indonesian translation is called Restorative justice. Restorative justice contains the meaning, namely: "a restoration of relations and atonement for the wrongdoing that the perpetrator of the crime (his family) wants to do against the victim of the crime (his family) (peace effort) outside the court with the aim and aim that legal problems arise as a result. the occurrence of the criminal act can be resolved properly by reaching an agreement between the parties ".

The justice that has been going on in the criminal justice system in Indonesia is retributive justice. Whereas what is expected is Restorative justice, namely justice is a process where all parties involved in a certain criminal act jointly solve the problem of how to deal with the consequences in the future. Restorative justice is a criminal case settlement model that prioritizes the recovery of victims, perpetrators and society. The main principle of Restorative justice is the participation of victims and perpetrators, citizen participation as facilitators in solving cases, so that there is a guarantee that children or perpetrators will no longer disturb the harmony that has been created in society. ${ }^{5}$

Restorative justicein the criminal law system in Indonesia, namely focusing on the needs of both victims and perpetrators of crimes. In addition, the Restorative justice approach helps criminals to avoid other crimes in the future.

\subsection{Implementation of Restorative justice in Settlement of Complaint Offenses}

The application of Restorative justice in the settlement of criminal cases does not necessarily cover all criminal acts committed. There are restrictions on criminal acts that can apply to settlement outside the court. According to Mudzakkir6, put forward several categorizations as benchmarks and scope for cases which can be resolved out of court through Penal Mediation, are as follows:

- Violation of criminal law is included in the category of complaint offense, whether it is an absolute complaint or a complaint that is relative in nature.

- Violation of the criminal law is subject to a fine as a criminal threat and the offender has paid the fine (Article 80 of the Criminal Code).

- Violation of the criminal law is included in the category of "offense", not "crime", which is only punishable by a fine.

- Violations of criminal law include criminal acts in the field of administrative law that place criminal sanctions as ultimum remedium.

\footnotetext{
${ }^{5}$ Herlina, Apong, dkk. (2004). Perlindungan Terhadap Anak Yang Berhadapan Dengan Hukum. Jakarta: Raja Grafindo Persada.

${ }^{6}$ Mudzakkir, dalam I Made Agus Mahendra Iswara. (2013). "Mediasi Penal Penerapan Nilai-Nilai Restoratif Justice dalam Penyelesaian Tindak Pidana Adat Bali". Jakarta: Tesis, Program Pascasarjana Fakultas Hukum Universitas Indonesia. p. 55-56
} 
- These violations of criminal law are categorized as light / completely minor and law enforcement officials use their powers to exercise discretion.

- Ordinary criminal law violations that are terminated or not processed in court (Deponir) by the Attorney General in accordance with their legal authority.

- Violations of criminal law are included in the category of violations of customary criminal law which are resolved through customary institutions.

Judging from the perpetrator, for criminal cases where the perpetrator commits a relatively serious mistake, Restorative justice tends not to be applied. As for criminal cases with perpetrators of minors (18 years and under), the perpetrators are old enough, the perpetrators are not recidivists, the possibility is open to seek settlement outside the court.

There are several crimes that are not appropriate if resolved out of court, such as:

- The crime of murder;

- Criminal acts of sexual violence against children;

- Drug crime;

- Criminal acts that cause widespread unrest in the community, such as religious blasphemy;

- Criminal acts against the state, such as corruption, terrorism, against natural resources;

- Recidive crime.

Police investigators as the starting gate of the criminal case settlement process provide an opportunity for victims to reconsider whether to continue choosing the legal process or preferring to make peace through a penal mediation mechanism. Investigators should position themselves as mediators in building communication between perpetrators and victims in order to achieve a sense of justice and benefit for all parties. If at the penal mediation stage it is agreed that there is peace, then the complaint from the victim will be withdrawn and this can be used as a basis for investigators to stop the investigation process. If the police are successful in directing the settlement of a complaint offense case through Restorative justice, the police can focus more on other more serious criminal cases.

The implementation of Restorative justice in the settlement of criminal cases of complaint offenses at the Cirebon City Police using a retributive approach (retaliation) can shift to a restorative approach (recovery). The reason behind the complaint offense was to give the victim the opportunity to consider the advantages and disadvantages before finally deciding to make a complaint to the police. If it is felt that it will only cause harm to the victim, there is no need to make a complaint. Prosecution in a criminal offense can only be carried out when there is a will or will of the victim through the complaint he makes. Therefore, it is possible to settle amicably and deliberately outside the court by means of penal mediation. Through this penal mediation, the victim and the perpetrator can both convey their wishes and be mediated by the police as the mediator. Therefore, there is a need for a strong legal basis for the police to direct the settlement of complaint offenses using a Restorative justice approach. 


\subsection{Constraints to the Implementation of Restorative justice in the Settlement of Complaint Offenses and their solutions}

Law as an institution that is most attached to human life, always associates with others or knowledge of law, which is managed by a law faculty or other approved educational institution. In studying law, it cannot be separated from other sciences because it will always be related to human behavior in society (behavioral science) and social sciences, a law degree must be able to integrate juridical and social sciences approaches. This ability must and will be obtained gradually if it is always recognized that the law is always in touch with society. ${ }^{7}$

The concept of the Restorative justice approach is an approach that focuses more on the conditions of creating justice and balance for the perpetrators of criminal acts and the victims themselves. ${ }^{8}$ Criminal procedures and justice mechanisms that focus on punishment are transformed into a dialogue and mediation process to create an agreement on the settlement of criminal cases that is more just and balanced for the victim and the perpetrator. Restoration includes restoring the relationship between the victim and the perpetrator. This rapprochement can be based on mutual agreement between the victim and the perpetrator. ${ }^{9}$ The victim can convey about the losses he has suffered and the perpetrator is given the opportunity to make amends, through compensation, peace, social work, and other agreements. ${ }^{10}$

The out-of-court problem solving efforts carried out by the criminal offender (his family) and the victim of the crime (his family) are expected to be the basis for consideration in the process of examining the criminal offender in court in the imposition of criminal sanctions by the judge / panel of judges. Justice is a consideration in the criminal law implementation system and is included in the new Criminal Code (KUHP) Regulations, especially for complaint criminal offenses (Klacht delict) so that it focuses on conditions of creating justice and balancing legal treatment of criminals and victims of criminal acts can be achieved properly, without always using criminal sanctions (imprisonment) in its final solution. Due to the deterrent effect as the ultimate goal of punishment (imprisonment), the perpetrators of criminal acts are no longer achieving their targets as expected. There needs to be a breakthrough in the implementation of the criminal system in Indonesia, not only through imprisonment alone but also through the application of Restorative justice. ${ }^{11}$

The ultimate goal of the concept of Restorative justice is to remove the stigma and return the criminals to become normal human beings, the perpetrators of

\footnotetext{
${ }^{7}$ Sukarmi. (2013). Psikologi Umum. Semarang: Unissula Press. p. 8

8 Reimer, Kristin. (2011). An Exploration Of The Implementation Of Restorative Justice In An Ontario Public School. Canadian Journal of Educational Administration and Policy, Issue \#119, March 11, by CJEAP and the author(s).p. 4

9 UNODC. (2006). Handbook on Restorative Justice Programmes. Vienna: UN New York: Criminal Justice Handbook Series. p. 5

${ }^{10}$ Reimer, Kristin. Op.cit, p. 6

11 Nurwianti, Annis. Gunarto, Sri Endah Wahyuningsih, Implementasi Restoratif / Restorative Justice Dalam Penyelesaian Tindak Pidana Kecelakaan Lalu Lintas Yang Dilakukan Oleh Anak Di Polres Rembang Jurnal Hukum Khaira Ummah Vol. 12. No. 4 December 2017
} 
crimes can realize their mistakes, so they do not repeat their actions, do not cause resentment because the perpetrators have been forgiven by the victims, the victims quickly get compensation, empower the community to overcome crimes and, reintegration of the perpetrators of crime in society. ${ }^{12}$

Whereas another problem area is where the victim or reporter wants the goods or losses suffered by the offender to be returned or it is reported as having occurred, making the victim or the reporter think the case is finished. It is different from the process or stages in an investigation where the police do not remove compensation for crimes. Therefore, the application of Restorative justice in the investigation process is very necessary in accelerating the resolution of problems / disputes and the most important thing is to achieve justice for the plaintiff / dispute. ${ }^{13}$

There are three basic principles that make up Restorative justice, namely:

- Restoration for those who have suffered losses due to crimes;

- The perpetrator has the opportunity to be involved in the recovery of the country; and

- Courts act to maintain public order and society acts to keep peace just.

Of the three basic principles, it is known that Restorative justice will provide feedback for the perpetrators, victims and people involved in it. Retorative justice also allows imprisonment if the sanction is the demands of the victims and it is true that by carrying out such sanctions the perpetrator is considered to be accountable for their actions. ${ }^{14}$

The implementation of Restorative justice in the settlement of criminal offenses complaints has several obstacles, including:

- The investigative authority granted by the Criminal Procedure Code is the authority to prove a criminal act and find suspects who must be accounted for in court.

- In the Criminal Procedure Code, investigators are given the authority to stop an investigation on the basis that it is not a criminal act, insufficient evidence as a criminal act, and for the sake of the law.

- KUHAP regulates the withdrawal of reports or complaints only for certain cases, namely those that constitute offenses for complaints.

Efforts to overcome obstacles in the implementation of Restorative justice in the settlement of complaint offenses include:

- According to the social jurispurdence theory that law is born from society, therefore the peak value of success depends on the awareness of the community itself with the investigator as a facilitator, namely submitting the final decision to the community through mutual agreement.

\footnotetext{
12 Ibnu Suka, Gunarto, Umar Ma'ruf, Peran Dan Tanggung Jawab Polri Sebagai Penegak Hukum Dalam Melaksanaan Restorative Justice Untuk Keadilan Dan Kemanfaatan Masyarakat, Jurnal Hukum Khaira Ummah Vol. 13. No. 1 March 2018

13 Ragil Tri Wibowo and Akhmad Khisni, Restorative Justice in Application for Crime Investigation on Property, Jurnal Daulat Hukum Volume 1 No. 2 June 2018 ISSN: 2614-560X 10.30659/jdh.1.2.565 570

14 Yudi Hendarto and Umar Ma'ruf, Diversion In Children Criminal Justice System Through Restorative Justice, Jurnal Daulat Hukum Volume 1 Issue 2, June 2018 ISSN: 2614-560X
} 
- Propose to the highest leadership to formulate a definite rule or organizational mission and the purpose of establishing a system (legalization) for the application of Restorative justice which functions as a recovery based on the usefulness and justice principles in a formal manner, such as attractive rules such as KUHAP and KUHP.

- Conducting outreach to the public regarding the role and duties of the police, especially in modern law enforcement based on dynamic and flexible law enforcement.

\section{Closing}

Restorative justicein the criminal law system in Indonesia, namely focusing on the needs of both victims and perpetrators of crimes. In addition, the Restorative justice approach helps criminals to avoid other crimes in the future. The implementation of Restorative justice in the settlement of criminal cases of complaint offenses using a retributive approach (retaliation) can shift to a restorative approach (recovery). Constraints to the Implementation of Restorative justice in Completion of Criminal Offenses and their Solutions. The obstacles: a. The investigative authority granted by the Criminal Procedure Code is the authority to prove a crime and find suspects who must be accounted for in court. b. In the Criminal Procedure Code, investigators are given the authority to stop an investigation on the basis of the consideration that it is not a criminal act, insufficient evidence as a criminal act, and for the sake of the law. c. KUHAP regulates the withdrawal of reports or complaints only for certain cases, namely those which constitute offenses for complaints. The solution: a. According to the social jurispurdence theory that law is born from society, therefore the peak value of success depends on the awareness of the community itself with the investigator as a facilitator, namely submitting the final decision to the community through mutual agreement. b. Propose to the highest leadership to formulate a definite rule or organizational mission and the purpose of establishing a system (legalization) for the application of Restorative justice which functions as a recovery based on the usefulness and justice principles in a formal manner, such as attractive rules such as KUHAP and KUHP. c. Conducting outreach to the public regarding the role and duties of the police, especially in modern law enforcement based on dynamic and flexible law enforcement.

So that the future application of Restorative justice in the settlement of criminal cases is not only involved in minor criminal cases but all general crimes based on the results of the coordination between the victim, the suspect, and the community and the police as facilitators also based on the results of thoughts to what extent the level of general interest is. Improve the ability of investigators, especially in the field of law enforcement so as to increase the professionalism and proportionality of the police in the community, especially in the implementation of Restorative justice. There needs to be socialization to the community regarding the implementation of the police's duties, especially in the field of law enforcement, but it must be based on definite rules from the police. 


\section{References}

\section{Journals:}

[1] Ibnu Suka, Gunarto, Umar Ma'ruf, Peran Dan Tanggung Jawab Polri Sebagai Penegak Hukum Dalam Melaksanaan Restorative justice Untuk Keadilan Dan Kemanfaatan Masyarakat, Jurnal Hukum Khaira Ummah Vol. 13. No. 1 March 2018

[2] Mudzakkir, dalam I Made Agus Mahendra Iswara. (2013). "Mediasi Penal Penerapan Nilai-Nilai Restoratif Justice dalam Penyelesaian Tindak Pidana Adat Bali". Jakarta: Tesis, Program Pascasarjana Fakultas Hukum Universitas Indonesia.

[3] Nurwianti, Annis. Gunarto, Sri Endah Wahyuningsih, Implementasi Restoratif / Restorative justice Dalam Penyelesaian Tindak Pidana Kecelakaan Lalu Lintas Yang Dilakukan Oleh Anak Di Polres Rembang Jurnal Hukum Khaira Ummah Vol. 12. No. 4 December 2017

[4] Ragil Tri Wibowo and Akhmad Khisni, Restorative justice in Application for Crime Investigation on Property, Jurnal Daulat Hukum Volume 1 No. 2 June 2018 ISSN: 2614-560X 10.30659/jdh.1.2.565 - 570

[5] Reimer, Kristin. (2011). An Exploration Of The Implementation Of Restorative justice In An Ontario Public School. Canadian Journal of Educational Administration and Policy, Issue \#119, March 11, by CJEAP and the author(s).

[6] Yudi Hendarto and Umar Ma'ruf, Diversion In Children Criminal Justice System Through Restorative justice, Jurnal Daulat Hukum Volume 1 Issue 2, June 2018 ISSN: 2614-560X

\section{Books:}

[1] Dikdik M. Arief Mansur \& Elisatri Gultom. (2008). Urgensi Perlindungan Korban Kejahatan Antara Norma Dan Realita. Jakarta: Raja Grafindo.

[2] Hartono, Sunaryati. (1994). Penelitian Hukum Indonesia Pada Akhir Abad ke20. Bandung: Alumni.

[3] Herlina, Apong, dkk. (2004). Perlindungan Terhadap Anak Yang Berhadapan Dengan Hukum. Jakarta: Raja Grafindo Persada.

[4] Sukarmi. (2013). Psikologi Umum. Semarang: Unissula Press.

[5] UNODC. (2006). Handbook on Restorative justice Programmes. Vienna: UN New York: Criminal Justice Handbook Series.

[6] Waluyo, Bambang. (2012). Viktimologi perlindungan korban dan saksi. Jakarta: Sinar Grafika.

[7] Widiartana, G. (2014). Viktimologi Perspektif Korban dalam Penanggulangan Kejahatan. Yogyakarta: Universitas Atma Jaya. 